\section{Evaluation of transsurgical stress in bitches submitted to ovariosalpingohisterectomy under infusions of fentanyl, lidocaine, and ketamine, associated or not with dexmedetomidine}

\author{
Avaliação do estresse transcirúrgico em cadelas submetidas à \\ ovariosalpingohisterectomia sob infusões de fentanil, lidocaína \\ e de cetamina, associada ou não à dexmedetomidina
}

\author{
Kleyton Domingos de Melo* (D), Ana Paula Monteiro Tenório² (D), Eduardo Alberto Tudury² (D), \\ Mauro de Araujo Penaforte Junior ${ }^{1}$ (D), Sabrina Candido Trajano ${ }^{1}$ (D) Maria Sheila da Silva Ferreira ${ }^{1}$ (D), \\ Gabriela Ratis Galeas 3 (D) \& Karina Silva Camargo 3 (D) \\ 'Veterinarian, MSc. Programa de Pós-graduação em Medicina Veterinária - PPGMV, Universidade Federal Rural de Pernambuco \\ -UFRPE, Recife, PE, Brasil \\ ²Veterinarian, DSc. Departamento de Medicina Veterinária - DMV, Universidade Federal Rural de Pernambuco - UFRPE, Recife, PE, Brasil \\ ${ }^{3}$ Curso de Graduação em Medicina Veterinária, Departamento de Medicina Veterinária - DMV, Universidade Federal Rural de \\ Pernambuco - UFRPE, Recife, PE, Brasil
}

How to cite: Melo, K. D., Tenório, A. P.M., Tudury, E. A., Penaforte Junior, M. A., Trajano, S. C., Ferreira, M. S. S., Galeas, G. R., \& Camargo, K. S. (2020). Evaluation of transsurgical stress in bitches submitted to ovariosalpingohisterectomy under infusions of fentanyl, lidocaine, and ketamine, associated or not with dexmedetomidine. Brazilian Journal of Veterinary Medicine, 42, e105320. https://doi. org/10.29374/2527-2179.bjvm105320

Financial support: Does not exist

Conflict of interests: No conflict of interests declared concerning the publication.

Received: May 10, 2019.

Accepted: August 03, 2020.

Thestudy was carried out at Hospital Veterinário, Departamento de Medicina Veterinária - DMV Universidade Federal Rural de Pernambuco UFRPE, Recife, PE, Brasil.

\section{*Correspondence}

Kleyton Domingos de Melo

Departamento de Medicina Veterinaria, Universidade Federal Rural de Pernambuco UFRPE, Campus Recife

Rua Dom Manuel de Medeiros, s/n, Dois Irmãos

CEP: 52171-900 - Recife (PE), Brasil

E-mail:kleytondomingos@hotmail.com

Keywords: analgesia, alpha-2agonists, N-methyl-D-Aspartate.

\title{
Resumo
}

Cetamina e dexmedetomidina são fármacos com propriedades analgésicas indicados para controlar a dor cirúrgica. O objetivo deste estudo foi verificar o aumento do cortisol e glicemia através da infusão continua com dexmedetomidina e cetamina em cirurgia de ovariosalpingohisterectomia em cadelas, quando comparado ao uso do FLK (fentanil, lidocaína e cetamina) e ao grupo controle (sem analgesia transcirurgica). Para tal experimento foram utilizadas 40 cadelas jovens (3,8 $\pm 2,8$ anos), sem raça definida, com massa corpórea média de 9,8 2,4 kg. Esses animais foram alocados em 5 grupos de acordo com a técnica anestésica preconizada: o grupo GCO considerado o controle para dor; no grupo GFLK, considerado 
controle para analgesia, procedeu-se infusão continua de fentanil (50 $\mu \mathrm{g} / \mathrm{mL}$ ), cetamina (30 mg) e lidocaína (150 mg) ou FLK diluídos em 500 mL de solução fisiológica a 0,9\% e infudidos, após bolus de fentanil na dose de $5 \mu \mathrm{g} / \mathrm{kg}$, a uma taxa de $10 \mathrm{mg} / \mathrm{kg} / \mathrm{h}$, equivalente a: $0,03 \mu \mathrm{g} / \mathrm{kg} / \mathrm{min}$ de fentanil, associados a $50 \mu \mathrm{g} / \mathrm{kg} / \mathrm{min}$ de lidocaína e 10 mg/kg/min de cetamina; cerca de 5 minutos antes da incisão cirúrgica; no grupo GCE foi infundido no momento da cirurgia apenas com cetamina na dose de $10 \mu \mathrm{g} / \mathrm{kg} / \mathrm{min}$, após administração intravenosa de 2 mg/kg; no grupo GDEX, a infusão foi feita com dexmedetomidina 2 $\mu \mathrm{g} / \mathrm{kg}$ diluída em um volume de 20 mL de $\mathrm{NaCl}$ 0,9\%, iniciando com uma infusão de 2 g/kg em 5 minutos, seguida de uma taxa de infusão de $2 \mu \mathrm{g} / \mathrm{kg} / \mathrm{h}$; já o grupo GDEXCE recebeu um bolus de dexmedetomidina $2 \mu \mathrm{g} / \mathrm{kg}$ mais cetamina $2 \mathrm{mg} / \mathrm{kg}$ diluída em $20 \mathrm{~mL}$ de solução de $\mathrm{NaCl}$ 0,9\%, por via intravenosa, durante um período de cinco minutos. Na sequência, procedeu-se a infusão do alfa-2 agonista na dose de $2 \mu \mathrm{g} / \mathrm{kg} / \mathrm{h}$, diluída em $20 \mathrm{~mL}$ de $\mathrm{NaCl}$ 0,9\%, mais cetamina por infusão contínua de $10 \mu \mathrm{g} / \mathrm{kg} / \mathrm{min}$. De acordo com os resultados obtidos, pôde-se verificar que houve redução significativa na dose de cortisol no M5 dos animais do grupo GDEXCE quando comparado ao grupo GCO, porém os valores de cortisol e glicemia no momento pós-extubação foram influenciados pela ação dos fármacos. Logo, o cortisol e glicemia não são considerados parâmetros eficazes para avaliação do estresse transcirúrgico em cadelas anestesiadas com dexmedetomidina mais cetamina submetidas à ovariosalpingohisterectomia; considerando os parâmetros hemodinâmicos e comportamentais, nos animais do grupo GDEXCE, a dexmedetomidina associada com cetamina reduziu o estresse cirúrgico dos animais em estudo.

Palavras-chave: analgesia, alpha-2-agonistas, N-metil-D-Aspartato

\section{Introduction}

Pain is an unpleasant sensation whose primary function is to serve as an alarm to protect the organism (Fein et al., 2011). The American Agency for Research and Quality in Health and the American Pain Society describe pain as the fifth vital sign, which should be assessed as automatically as the patient's other vital signs such as: heart rate (pulse), respiratory rate, blood pressure, and body temperature (Bottega \& Fontana, 2010).

Surgical analgesia in veterinary medicine has been one of the main goals of anesthesiologists as success in pain control is totally dependent on the choice of the protocol used in the pre- and transoperative periods. Surgical patients with a high level of pain and without adequate treatment may show delayed recovery and postsurgical complications (Deumens et al., 2013). Pain causes a series of changes in the endocrine system, which can increase cortisol levels (Castro Vaz et al., 2013). This influences the metabolism of carbohydrates, stimulating hepatic gluconeogenesis and reducing glycolysis by decreasing the use of peripheral glucose. It also interferes with the metabolism of lipids, impairing the transport of glucose to adipocytes, which reduces their sensitivity to insulin. These factors lead us to conclude that cortisol has a hyperglycemic action, that is, it increases blood glucose levels (Goutal et al., 2012; Marik \& Bellomo, 2013).

With the advance of research on anesthetic procedures in veterinary medicine, the simultaneous use of several categories of drugs has shown better outcomes in terms of pain reduction in comparison to the isolated use of drugs. Multimodal anesthesia acts on acute pain, involving the peripheral and central nervous systems and psychological components. This type of treatment combines analgesic drugs with different mechanisms of action and at lower doses to control pain without causing adverse effects (Chohan, 2010; Rosero \& Joshi, 2014).

The use of dexmedetomidine has been expanding both in human medicine (Afonso \& Reis, 2012) and in veterinary medicine (Uilenreef et al., 2008). In human medicine, some protocols using this drug have shown better results regarding hemodynamic stability, awakening condition, and anesthetic recovery in comparison to the use of sufentanil. Thus, it is indicated as an isolated analgesic in intraperitoneal surgeries (Marangoni et al., 2005). Also in human medicine, the use of dexmedetomidine associated with ketamine has shown a better response than ketamine alone or associated with midazolam during dressing changes in burned patients (Gündüz et al., 2011).

In veterinary medicine, dexmedetomidine associated with ketamine and lidocaine, administered intravenously, led to a lower rate of isoflurane vaporization in comparison to isolated ketamine or lidocaine infusions in bitches submitted to ovariosalpingohisterectomy (OSH) (Gutierrez-Blanco et al., 2013). The mechanism by which dexmedetomidine prevents the transmission of painful stimuli correlates with the inhibition of the release of neurotransmitters in the primary afferent fibers, which are responsible for the transmission of nociceptive stimuli to 
other neurons (Murrell \& Hellebrekers, 2005). More recent studies prove that the use of ketamine at low doses promotes analgesia. This effect is probably caused by the interaction with various types of receptors such as NMDA, GABAergics, serotoninergics, and even opioids, in addition to the action on the monoaminergic amine uptake system. These extra-NMDA receptor actions are still under study (Persson, 2013).

In this context, the present study evaluates the variation in serum cortisol and blood glucose levels in bitches undergoing ovariosalpingohisterectomy and submitted to continuous infusion with dexmedetomidine and ketamine. These treatments were compared with FLK infusion (fentanyl, lidocaine, and ketamine) for analgesia, and with the treatment of the control group (without transsurgical analgesia).

\section{Materials and methods}

The present research was approved by the Ethics Committee on Animal Use (CEUA) of the Federal Rural University of Pernambuco, under the license number 118/2017, attesting that the study followed the Ethical Principles of Animal Experimentation.

The experiment included 40 young ( $2.47 \pm 1.72$ years) mixed-breed bitches with average body weight of $10.5 \pm 2.01 \mathrm{~kg}$. These animals came from the Veterinary Hospital of the Department of Veterinary Medicine of the Rural Federal University of Pernambuco. After signing of the Informed Consent Term by the tutors, the patients were submitted to clinical examination and hematological evaluation to observe possible changes that would make the procedure unfeasible. Presurgical evaluation included complete blood count, platelet count, and biochemical tests to assess renal and hepatic function: urea, creatinine, alkaline phosphatase (AP), albumin, aspartate aminotransferase (AST), alanine aminotransferase (ALT), and abdominal ultrasound. After the examinations, the animals returned to their homes. The dogs able to perform the procedure had a scheduled day and hour of surgery and should perform an 8-hour food fasting and a 4-hour water fasting.

The animals were divided into five groups (GCO, GFLK, GCE, GDEX, and GDEXCE) according to the anesthetic technique to be used. Each group consisted of eight animals with body weight and age within the previously mentioned standards. All animals were operated during the morning due to cortisol variation and influence of the circadian cycle. All surgeries were performed by the same surgeon, with experience in the procedure, keeping approximately constant time, pattern, and technique.

On the day of the surgical-anesthetic procedure, the patients underwent a new physical evaluation, where the following were checked and recorded: heart rate (HR) values in beats per minute (bpm), respiratory rate (f) in movements per minute (mpm), body temperature (T) in degrees Celsius $\left({ }^{\circ} \mathrm{C}\right)$, capillary perfusion time (CPT), skin turgor (hydration), and systolic blood pressure (SBP) and diastolic blood pressure (DBP) through the noninvasive blood pressure (NIBP) method using the DL1100"blood pressure measurement device. After verifying that the parameters were normal for their respective species, the animals were referred for ovariosalpingohisterectomy following the anesthetic protocols according to the order of the groups.

These animals underwent abdominal trichotomy. A peripheral venous access for maintenance fluid therapy with saline solution was inserted at a rate of $10 \mathrm{~mL} / \mathrm{kg} /$ hour. All animals were premedicated with acepromazine ${ }^{1}(0.05 \mathrm{mg} / \mathrm{kg})$ plus tramadol hydrochloride ${ }^{2}(4 \mathrm{mg} / \mathrm{kg})$, both administered intramuscularly. Fifteen minutes after premedication, the animals were sent to the operating room and underwent anesthetic induction with intravenous (IV) propofol ${ }^{3}$ (4 mg/kg) and isoflurane maintenance with oxygen as 100\% diluting gas through the Baraka system. A new access (contralateral) was placed in the animals for coupling of the continuous infusion pump.

The animals were divided into five groups $(\mathrm{G})$ according to the drugs administered:

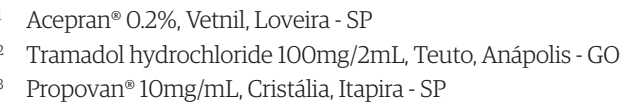


- Group 1 (GCO): control group for pain. Infusion with 0.9\% saline solution at an infusion rate of $10 \mathrm{~mL} / \mathrm{kg} / \mathrm{h}_{i}$

- Group 2(GFLK): control group for analgesia. Continuous infusion started about 5 minutes before surgical incision with fentanyl ${ }^{4}(50 \mu \mathrm{g} / \mathrm{mL})$, lidocaine ${ }^{5}(150 \mathrm{mg})$, and ketamine ${ }^{6}(30 \mathrm{mg})$,or FLK diluted in $500 \mathrm{~mL}$ of $0.9 \%$ saline solution at a rate of $10 \mathrm{~mL} / \mathrm{kg} / \mathrm{h}$, equivalent to: $0.03 \mu \mathrm{g} / \mathrm{kg} / \mathrm{min}$ of fentanyl associated with $50 \mu \mathrm{g} / \mathrm{kg} / \mathrm{min}$ of lidocaine and $10 \mu \mathrm{g} / \mathrm{kg} / \mathrm{min}$ of ketamine. Infusion with FLK started after fentanyl IV bolus at a dose of $5 \mu \mathrm{g} / \mathrm{kg}$;

- Group 3 (GCE): ketamine infusion at a rate of $10 \mu \mathrm{g} / \mathrm{kg} / \mathrm{min}$, after intravenous administration of this drug at a dose of $2 \mathrm{mg} / \mathrm{kg}$ in bolus (five minutes before surgical procedure);

- Group 4 (GDEX): infusion made with dexmedetomidine ${ }^{7}(2 \mu \mathrm{g} / \mathrm{kg}$ ) diluted in $20 \mathrm{~mL}$ of $0.9 \% \mathrm{NaCl}$, starting with an infusion of $2 \mu \mathrm{g} / \mathrm{kg}$ for 5 minutes (interval before the start of the surgical procedure), followed by an infusion rate of $2 \mu \mathrm{g} / \mathrm{kg} / \mathrm{h}$;

- Group 5 (GDEXCE):infusion started with dexmedetomidine ( $2 \mu \mathrm{g} / \mathrm{kg}$ ) plus ketamine ( $2 \mathrm{mg} / \mathrm{kg}$ ) diluted in $20 \mathrm{~mL}$ of $0.9 \% \mathrm{NaCl}$ solution, intravenously, at an infusion rate of $4 \mathrm{~mL} / \mathrm{min}$ for five minutes (time interval before the start of the surgical procedure). Subsequently, the alpha-2 agonist was infused at a rate of $2 \mu \mathrm{g} / \mathrm{kg} / \mathrm{h}$, diluted in $20 \mathrm{~mL}$ of $0.9 \% \mathrm{NaCl}$, and ketamine was continuously infused at a rate of $10 \mu \mathrm{g} / \mathrm{kg} / \mathrm{min}$.

The LF Inject infusion pump was used for drug administration, with $60 \mathrm{~mL}$ syringes being used for infusions of FLK and ketamine alone, and $20 \mathrm{~mL}$ syringes being used for infusions of dexmedetomidine and dexmedetomidine plus ketamine (infusion before the start of the surgical procedure). The FLK and ketamine solutions were previously prepared in a fluid bag of $500 \mathrm{~mL}$ of $0.9 \%$ saline solution, with quantities acquired according to the need for infusion. The dexmedetomidine and dexmedetomidine plus ketamine solutions were prepared proportionally, directly in the syringes.

The parameters oximetry, heart rate, respiratory rate, body temperature, systolic blood pressure (SBP), and diastolic blood pressure (DBP) were measured with a multiparametric monitor. Mean arterial pressure was measured through the calculation $(\mathrm{MAP}=\mathrm{DBP}+(\mathrm{SBP}-\mathrm{DBP}) / 3)$, where: MAP = Mean Arterial Pressure; SBP = Systolic Blood Pressure; DBP = Diastolic Blood Pressure

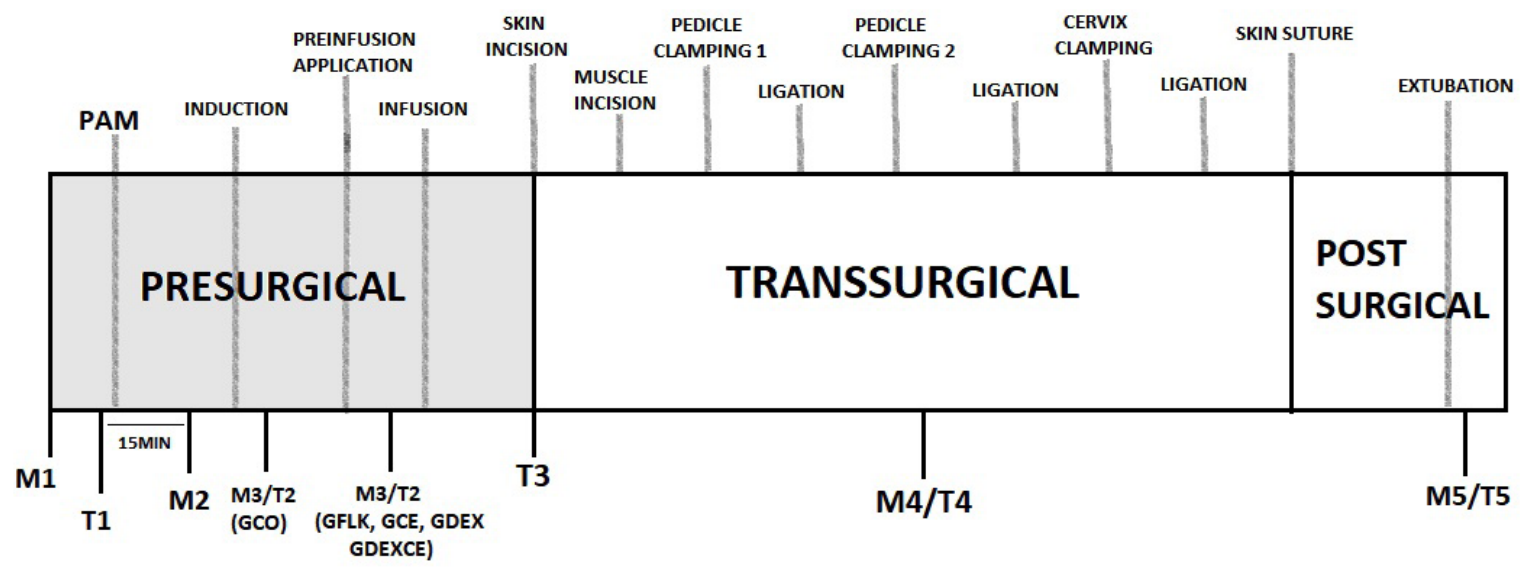

Figure 1. Schematic representation of the experimental moments for data collection during the study (Santos et al., 2015 - adapted).

(Nora \& Grobocopatel, 1996). These parameters were evaluated at the following times: before preanesthetic medication (PAM) (T1), after anesthetic induction and/or drug administration to

\footnotetext{
4 Fentanest ${ }^{\circledR} 0.0785 \mathrm{mg} / \mathrm{mL}$, Cristália, Itapira - SP

Xylestesin ${ }^{\circledast} \%$ (injectable solution), Cristália, Itapira - SP

Clortamina ${ }^{\circledR} 50 \mathrm{mg} / \mathrm{mL}$, Biochimico, Rio de Janeiro - RJ

Dexdomitor ${ }^{\circledast} 0.5 \mathrm{mg} / \mathrm{mL}$, Zoetis, Campinas - SP
} 
reach the serum level - preinfusion (T2), during skin incision(T3), during clamping of the ovarian pedicle (T4), and immediately after extubation (T5) (Figure 1).

To perform the surgical procedure, the room was maintained at a temperature of $29{ }^{\circ} \mathrm{C}$, excluding the use of a thermal mattress so as to avoid interference with the physiology of the animals; temperatures were measured in the oral cavity.

To assess immediate postsurgical pain, the University of Melbourne Pain Scale was used by a single examiner at about 1 hour after surgery. The values of the Melbourne scale range between 0 and 27, with 0 corresponding to absence of pain, and 27 corresponding to the worst pain. The assessment of the animals before PAM served as a basis for further comparison. In case any animal reached a score above 13 , analgesic rescue with morphine $(0.1 \mathrm{mg} / \mathrm{kg}$, IV) was provided.

To assess transsurgical stress, blood samples were taken to measure blood glucose and cortisol levels from the preanesthetic period until the immediate postoperative period (extubation). Blood samples were taken from the animals at 5 moments (M): first moment (M1), before preanesthetic medication (PAM), to obtain the baseline value; second moment (M2), fifteen minutes after PAM, to assess cortisol and blood glucose levels in tranquil animals; third moment (M3), after anesthetic induction with propofol (GCO) or afteof the drug to reach the serum level (GFLK, GCE, GDEX, GDEXCE), considering the moment of least stress for sedation; fourth moment (M4), during clamping and ligation of the second ovarian pedicle (moment of painful stimulus); fifth moment (M5), immediately after extubation for poststimulus evaluation (Figure 1).

The samples were taken from the jugular vein by using a $5 \mathrm{~mL}$ syringe, with a $25 \times 7$ hypodermic needle puncture, filling the entire volume. To measure cortisol, immediately after collection, $4.0 \mathrm{~mL}$ of the total blood sample was placed in a dry collection tube with a clot activator and then centrifuged at $1500 \mathrm{rpm}$ for 10 minutes. The serum sample obtained was frozen at $-20^{\circ} \mathrm{C}$ and processed in less than two months. A portion of the whole blood sample was used immediately after collection to obtain blood glucose values by using a capillary blood glucose device (Accu chek Active').

Before the start of the analyses, the frozen samples were kept at room temperature $\left(25^{\circ} \mathrm{C}\right.$ to $30^{\circ} \mathrm{C}$ ) for 30 minutes until thawing. Cortisol was analyzed through the fluorescent immunoassay (FIA) method by using the Ichroma Cortisol ${ }^{\mathrm{TM}}$ device. The process started by transferring $30 \mu \mathrm{L}$ of the serum sample to a tube containing the detection buffer. After closing the detection buffer tube, the sample was shaken vigorously about 10 times to homogenize the solution. Immediately after homogenization, $75 \mu \mathrm{L}$ of the prepared sample mixture was pipetted and this quantity was dispensed into the sample well of a cassette, which was individualized for each serum sample. After this process, the sample loaded cassette was inserted in an incubator at $25^{\circ} \mathrm{C}$ for 10 minutes. Then, the cassette was placed in the cassette holder of the Ichroma Reader ${ }^{\mathrm{TM}}$ for scanning and obtaining the results (Figure 2). The results were obtained in $\mathrm{nmol} / \mathrm{L}$; each value was recorded in a Table, and the data submittedto statistical analysis.

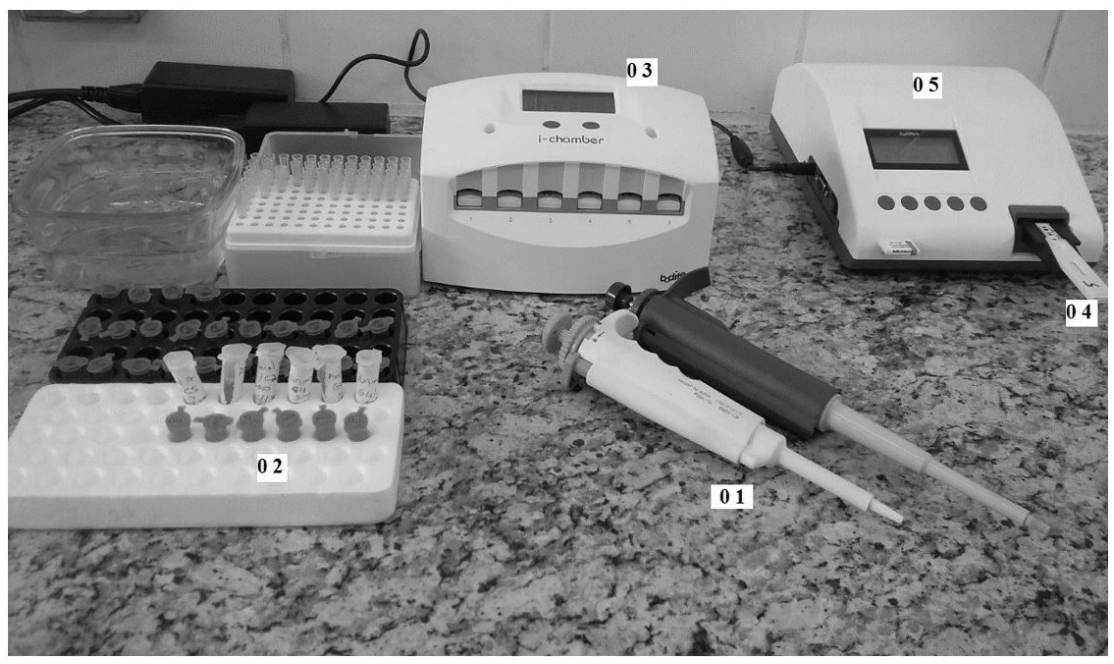

Figure 2. Cortisol analysis using the Ichroma Cortisol ${ }^{\mathrm{TM}}$ device, showing $30 \mu \mathrm{L}$ and $75 \mu \mathrm{L}$ pipettes $(\mathrm{O} 1)$, detection buffer tubes - orange color (02), incubator (03), sample loaded cassette (04), and scanner (05). 
For statistical analysis, a logarithmic transformation was initially performed for the results obtained from cortisol, blood glucose, heart and respiratory rates, NIBP, and pain scale. In addition, an angular transformation (arc sine) of the SPO2 values (\%) was performed. These transformations were necessary due to the high values of standard deviation and coefficient of variation in the samples. After these steps, all values obtained in the variables were tested for normality distribution using the Shapiro-Wilk test (Sampaio, 1998).

The comparison between the values obtained in the groups and moments was performed by means of analysis of variance (Test F) and by the Student-Newman-Keuls test when the distribution of values was normal (parametric analysis) or by the Kruskal Wallis test when the distribution was not normal (nonparametric analysis). For the comparison between the values obtained in the Melbourne pain scale in the groups, the Bonferroni test was used (Field, 2009). The IBM SPSS Statistics 23.0 program was used for statistical calculations and the significance level adopted was 5.0\%.

\section{Results}

There were no surgical or anesthetic complications in any of the procedures. The average weight of the animals in the groups was: $10.48 \pm 2.82$ (GCO); $10.01 \pm 1.98$ (GFLK); $10.58 \pm 1.51$ (GCE); $11.01 \pm 1.58$ (GDEX); and $10.41 \pm 2.18$ (GDEXCE). The average age, in years, was: $2.5 \pm 1.5$ (GCO); $2.37 \pm 1.62$ (GFLK); $2.5 \pm 1.5$ (GCE); $2.75 \pm 2.25$ (GDEX); and $2.25 \pm 1.75$ (GDEXCE). There were no significant differences between groups ( $\mathrm{p}>0.05$ ).

Since drug administration in the GDEXCE group (dexmedetomidine plus ketamine) occurred after induction with propofol, the cataleptoid effect reported by Hatschbach et al. (2005) was not observed.

Table1 shows that among the groups under study, heart rate was significantly lower for GDEX and GDEXCE.

Table 1. Physiological parameters of animals undergoing ovariosalpingohisterectomy, analyzed in each group.

\begin{tabular}{cccccc}
\hline Group $^{*}$ & HR $(\mathbf{b p m})^{1}$ & RR $(\mathbf{m p m})^{2}$ & T $\left({ }^{\circ} \mathbf{C}\right)^{1}$ & SPO2 $(\%)^{1}$ & MAP $(\mathbf{m m H g})^{1}$ \\
\hline GCO & $107.5 \pm 22.7^{\mathrm{b}}$ & $13.3 \pm 6.3$ & $36.5 \pm 0.5^{\mathrm{c}}$ & $99.0 \pm 0.0$ & $91.3 \pm 25.0^{\mathrm{b}}$ \\
GFLK & $101.7 \pm 15.7^{\mathrm{b}}$ & $13.4 \pm 6.3$ & $36.2 \pm 0.5^{\mathrm{d}}$ & $99.0 \pm 0.0$ & $88.0 \pm 26.5^{\mathrm{b}}$ \\
GCE & $115.2 \pm 21.4^{\mathrm{a}}$ & $12.2 \pm 5.8$ & $36.4 \pm 0.5^{\mathrm{d}}$ & $99.0 \pm 0.0$ & $90.7 \pm 25.6^{\mathrm{b}}$ \\
GDEX & $76.2 \pm 19.1^{\mathrm{d}}$ & $11.9 \pm 5.8$ & $36.9 \pm 0.5^{\mathrm{b}}$ & $99.0 \pm 0.0$ & $98.6 \pm 19.9^{\mathrm{b}}$ \\
GDEXCE & $85.8 \pm 14.9^{\mathrm{c}}$ & $10.4 \pm 4.0$ & $37.2 \pm 0.3^{\mathrm{a}}$ & $99.0 \pm 0.0$ & $107.1 \pm 25.8^{\mathrm{a}}$ \\
\hline
\end{tabular}

*Mean and standard deviation in each group; 'Student-Newman-Keuls test; ${ }^{2}$ Kruskal-Wallis test; different letters in the same column indicate statistical difference $(p<0.05)$ between groups. HR (Heart Rate) RR (Respiratory Rate) T(Bory Temperature) SPO2 (Oxygen Saturation) MAP (Mean Arterial Pressure).

Body temperature (T) decreased in relation to baseline in the five groups, although GDEXCE has shown a smaller decrease of this variable. Although decreasing, the body temperature of the animals in this study remained within the physiological standards during surgical procedures.

Mean values of respiratory rate and oximetry did not differ between the five groups, while MAP values were significantly higher in GDEXCE.

The analysis of heart rate at each moment (Table 2; Figure 3) shows that this variable decreased for the groups GCE, GDEX, and GDEXCE at M5 in relation to the previous moment (M4), which was not observed in the groups GCO and GFLK. The GCO group (pain control) had the greatest increase at M5 in comparison to baseline (M1). The heart rate values of GDEX and GDEXCE at M5 were very close to baseline values. 
Table 2. Heart rate (HR) values (bpm) between moments in the groups.

\begin{tabular}{cccccc}
\hline \multirow{2}{*}{ Group } & \multicolumn{5}{c}{ Moment*1 $^{*}$} \\
\cline { 2 - 6 } & $\mathbf{1}$ & $\mathbf{2}$ & $\mathbf{3}$ & $\mathbf{4}$ & $\mathbf{5}$ \\
\hline GCO & $103.1 \pm 24.1$ & $107.9 \pm 22.3^{\mathrm{A}}$ & $106.5 \pm 13.5^{\mathrm{AB}}$ & $106.6 \pm 15.2^{\mathrm{AB}}$ & $113.5 \pm 36.3^{\mathrm{A}}$ \\
GFLK & $104.6 \pm 14.2$ & $97.9 \pm 18.5^{\mathrm{A}}$ & $104.0 \pm 12.1^{\mathrm{ABC}}$ & $97.5 \pm 14.1^{\mathrm{ABC}}$ & $104.6 \pm 20.5^{\mathrm{A}}$ \\
GCE & $110.8 \pm 24.1$ & $117.2 \pm 20.3^{\mathrm{A}}$ & $113.1 \pm 14.1^{\mathrm{A}}$ & $121.0 \pm 33.5^{\mathrm{A}}$ & $113.7 \pm 13.2^{\mathrm{A}}$ \\
GDEX & $87.7 \pm 21.4$ & $64.3 \pm 19.7^{\mathrm{B}}$ & $80.0 \pm 20.4^{\mathrm{C}}$ & $75.7 \pm 16.5^{\mathrm{C}}$ & $73.0 \pm 13.5^{\mathrm{B}}$ \\
GDEXCE & $85.2 \pm 13.4$ & $76.1 \pm 13.4^{\mathrm{B}}$ & $86.1 \pm 23.7^{\mathrm{BC}}$ & $92.9 \pm 8.9^{\mathrm{BC}}$ & $89.0 \pm 7.7^{\mathrm{AB}}$ \\
\hline
\end{tabular}

*Mean and standard deviation; 'Student-Newman-Keuls test; different uppercase letters in the same column indicate statistical difference $(p<0.05)$ between groups; different lowercase letters in the same row indicate statistical difference $(p<0.05)$ between moments.

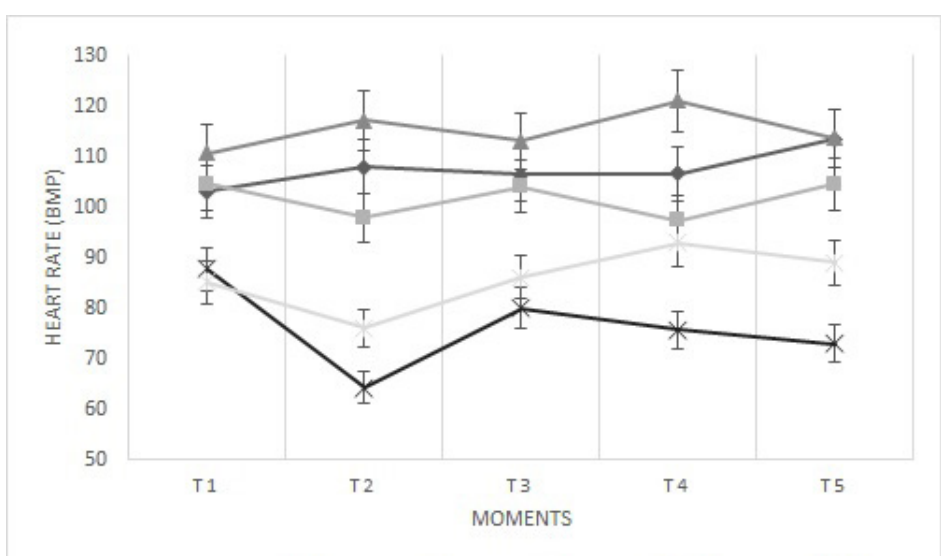

Figure 3. Heart Rate (BPM) relative to the groups and moments under study (before PAM, after anesthetic induction (GCO) and/or drug administration to reach the serum level (GFLK, GCE, GDEX, GDEXCE), during skin incision, during clamping of the ovarian pedicle, and immediately after extubation.

Observing heart rate moments between the groups GDEX and GDEXCE, it appears that ketamine increases heart rate, although not from a statistical point of view, as there was no significant difference between these groups in the moments under study.

The assessment of mean arterial pressure showed a significant difference in GDEXCE in relation to the other groups, demonstrating an increase in values. This result was not observed in the GDEX group, with a decrease at M2 and subsequent increase (Table 3; Figure 4). In addition to the GDEX group, arterial pressure also decreased significantly at M2 in the groups GCO, GFLK, GCE, which was not observed in GDEXCE. Table 3 and Figure 4 show a significant increase in mean arterial pressure at M3 in GDEXCE in relation to that same moment in GDEX.

Table 3. Mean arterial pressure (MAP) values between moments in the groups.

\begin{tabular}{cccccc}
\hline \multirow{2}{*}{ Group } & \multicolumn{5}{c}{ Moment $^{* 1}$} \\
\cline { 2 - 6 } & $\mathbf{1}$ & $\mathbf{2}$ & $\mathbf{3}$ & $\mathbf{4}$ & $\mathbf{5}$ \\
\hline GCO & $113.0 \pm 17.0^{\mathrm{a}}$ & $60.6 \pm 7.3^{\mathrm{Bb}}$ & $88.5 \pm 14.2^{\mathrm{Aba}}$ & $96.5 \pm 20.3^{\mathrm{ABa}}$ & $98.2 \pm 28.7^{\mathrm{a}}$ \\
GFLK & $117.7 \pm 19.3^{\mathrm{a}}$ & $68.5 \pm 16.6^{\mathrm{ABb}}$ & $92.6 \pm 30.7^{\mathrm{ABb}}$ & $80.2 \pm 21.8^{\mathrm{Bb}}$ & $83.5 \pm 16.5^{\mathrm{b}}$ \\
GCE & $105.3 \pm 21.8^{\mathrm{a}}$ & $54.2 \pm 6.9^{\mathrm{Bb}}$ & $93.7 \pm 16.1^{\mathrm{Aba}}$ & $89.3 \pm 19.2^{\mathrm{ABa}}$ & $110.7 \pm 16.2^{\mathrm{a}}$ \\
GDEX & $118.1 \pm 18.9^{\mathrm{a}}$ & $78.9 \pm 12.1^{\mathrm{Ab}}$ & $85.7 \pm 12.2^{\mathrm{Bb}}$ & $106.8 \pm 12.8^{\mathrm{Aa}}$ & $103.7 \pm 14.5^{\mathrm{a}}$ \\
GDEXCE & $109.2 \pm 14.5$ & $82.6 \pm 22.1^{\mathrm{A}}$ & $116.0 \pm 23.8^{\mathrm{A}}$ & $115.1 \pm 22.7^{\mathrm{A}}$ & $112.7 \pm 32.1$ \\
\hline
\end{tabular}

*Mean and standard deviation; 'Student-Newman-Keuls test; different uppercase letters in the same column indicate statistical difference $(p<0.05)$ between groups; different lowercase letters in the same row indicate statistical difference $(p<0.05)$ between moments. 


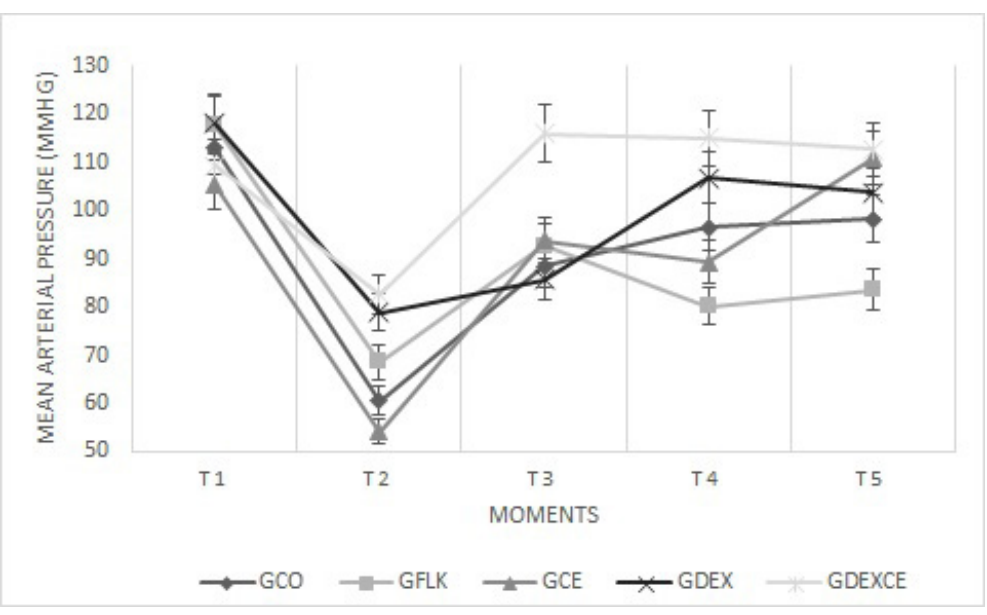

Figure 4. Mean Arterial Pressure (mmHg) relative to the groups and moments under study (before PAM, after anesthetic induction (GCO) and/or drug administration to reach the serum level (GFLK, GCE, GDEX, GDEXCE), during skin incision, during clamping of the ovarian pedicle, and immediately after extubation.

The results of the Melbourne pain scale (Figure 5) show a significantly lower average for this variable in the groups GDEX and GDEXCE. In this assessment, GDEX results were compared with those of the GFLK, and the GDEXCE group showed better analgesic response than the groups GCO, GCE, and GFLK, according to the averages obtained.

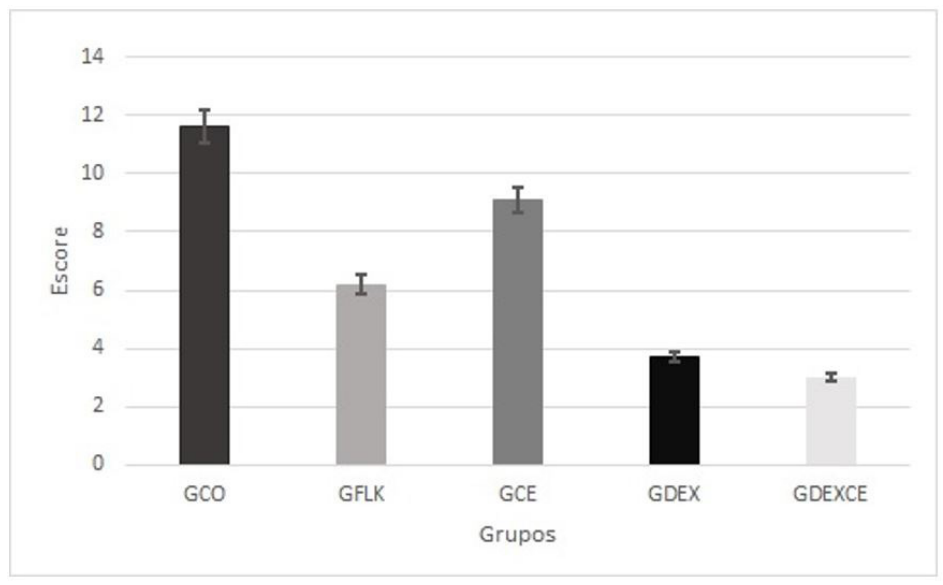

Figure 5. Imputed values (points) of the Melbourne scale in the different groups.

There was no statistical difference between the average values of GCO and GCE. The University of Melbourne Pain Scale parameter most prevalent in both GCO and GCE was the presence of vocalization during the immediate postoperative period. There was a significant increase in the Melbourne pain scale in the groups GCO (pain control) and GCE (ketamine infusion). Excessive salivation was the most prevalent change in the groups GFLK and GCE, respectively.

In the groups GFLK, GDEX, and GDEXCE, the return of animals from post extubation anesthesia was smooth, with greater sedation in the animals of GDEX and GDEXCE in comparison to the other groups under study.

The results of the cortisol level in the groups (Table 4) showed only a statistical difference between Groups 1 and 2 (GCO and GFLK); cortisol showed higher levels of significance in GCO than in GFLK. In turn, the other groups did not show a significant decrease in cortisol in comparison to the groups GCO and GFLK. 
Table 4. Cortisol values (nmol/L) in the groups.

\begin{tabular}{cc}
\hline Group & Cortisol $^{* 1}$ \\
\hline GCO & $284.4 \pm 116.6^{\mathrm{A}}$ \\
GFLK & $200.6 \pm 118.7^{\mathrm{B}}$ \\
GCE & $224.9 \pm 132.3^{\mathrm{AB}}$ \\
GDEX & $217.9 \pm 96.0^{\mathrm{AB}}$ \\
GDEXCE & $222.0 \pm 113.0^{\mathrm{AB}}$ \\
\hline
\end{tabular}

*Mean and standard deviation;

'Student-Newman-Keuls test; different letters in the same column indicate statistical difference $(p<0.05)$ between groups

According to the level of cortisol between moments in the groups (Table 5; Figure 6), GCO showed a significant increase in cortisol in comparison to GDEXCE at M4, and GDEX had a lower cortisol level at M5 in comparison to the other groups. Also in this analysis, GCO showed a higher concentration of cortisol at M5 in comparison to M3; GDEX did not show a significant difference in cortisol at the moments under study; and GDEXCE only showed a significant increase in cortisol at M5 in comparison to other groups at other moments. Only GDEX and GDEXCE did not show a significant increase in cortisol at M4 in comparison to M3. Only GDEX did not show a significant increase at M5 in comparison to baseline.

Table 5. Cortisol values (nmol/L) between moments in the groups.

\begin{tabular}{cccccc}
\hline \multirow{2}{*}{ Group } & \multicolumn{5}{c}{ Moment $^{* 1}$} \\
\cline { 2 - 6 } & $\mathbf{1}$ & $\mathbf{2}$ & $\mathbf{3}$ & $\mathbf{4}$ & $\mathbf{5}$ \\
\hline GCO & $265.7 \pm 135.3^{\mathrm{ab}}$ & $229.5 \pm 121.1^{\mathrm{ab}}$ & $205.7 \pm 100.6^{\mathrm{Abc}}$ & $343.8 \pm 59.3^{\mathrm{Aab}}$ & $378.2 \pm 65.7^{\mathrm{Aa}}$ \\
GFLK & $166.5 \pm 92.4^{\mathrm{bc}}$ & $140.8 \pm 72.7^{\mathrm{bc}}$ & $95.7 \pm 29.2^{\mathrm{BC}}$ & $233.7 \pm 96.3^{\mathrm{ABb}}$ & $366.2 \pm 63.3^{\mathrm{Aa}}$ \\
GCE & $233.9 \pm 136.6^{\mathrm{b}}$ & $108.5 \pm 56.7^{\mathrm{C}}$ & $124.5 \pm 65.3^{\mathrm{ABC}}$ & $278.2 \pm 87.5^{\mathrm{ABb}}$ & $379.1 \pm 78.7^{\mathrm{Aa}}$ \\
GDEX & $183.8 \pm 78.2^{\mathrm{Ba}}$ & $201.1 \pm 100.2$ & $175.1 \pm 101.7^{\mathrm{AB}}$ & $249.5 \pm 101.3^{\mathrm{AB}}$ & $279.8 \pm 72.9^{\mathrm{B}}$ \\
GDEXCE & $232.2 \pm 147.2^{\mathrm{b}}$ & $137.1 \pm 72.8^{\mathrm{b}}$ & $210.3 \pm 89.9^{\mathrm{Ab}}$ & $177.3 \pm 51.1^{\mathrm{Bb}}$ & $353.4 \pm 54.6^{\mathrm{Aa}}$ \\
\hline
\end{tabular}

*Mean and standard deviation;

'Student-Newman-Keuls test; different uppercase letters in the same column indicate statistical difference $(p<0.05)$ between groups; different lowercase letters on the same row indicate statistical difference $(p<0.05)$ between moments.

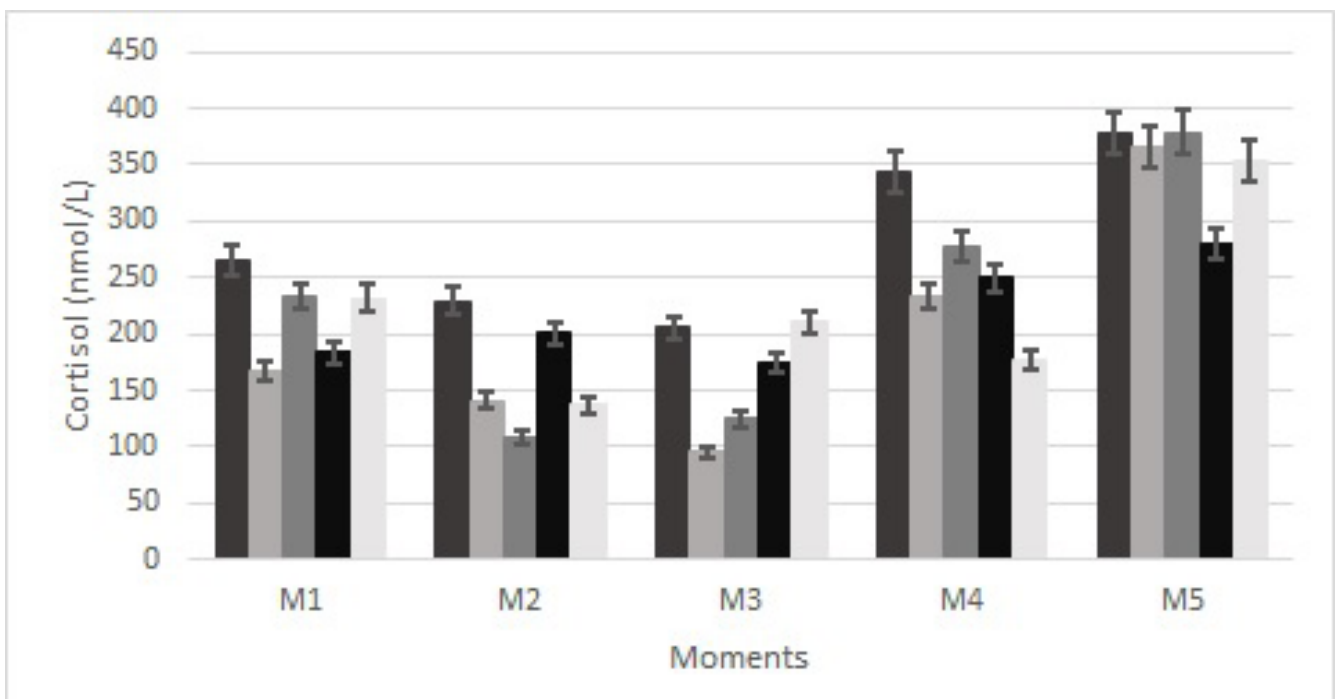

Figure 6. Graphical representation of the cortisol variation between moments (before PAM, after PAM, after anesthetic induction (GCO) or drug administration to reach the serum level (GFLK, GCE, GDEX, GDEXCE), during clamping and ligation of the ovarian pedicle, and immediately after extubation). 
In addition to the control group for pain (GCO), the groups that showed a significant increase in cortisol at M5 in comparison to M3 were: GFLK, GCE, and GDEXCE. In GDEX, there was no such significant increase.

Blood glucose levels did not differ significantly between the groups (Table 6).

Table 6. Blood glucose values (mg/dL) in the groups.

\begin{tabular}{cc}
\hline Group & Blood glucose $^{* 1}$ \\
\hline GCO & $96.2 \pm 12.9$ \\
GFLK & $104.1 \pm 25.9$ \\
GCE & $94.5 \pm 15.5$ \\
GDEX & $96.7 \pm 23.5$ \\
GDEXCE & $93.9 \pm 26.0$ \\
\hline
\end{tabular}

*Mean and standard deviation; 'Student-Newman-Keuls test; different letters in the same column indicate statistical difference $(p<0.05)$ between groups.

Notwithstanding, blood glucose levels between moments in the groups (Table 7; Figure 7) increased significantly at M5 in comparison to the previous moments in all treated groups, except for GCO (pain control). It is noteworthy that the increase in blood glucose was accompanied by an increase in cortisol in most of the moments in the groups, only differing in GDEXCE.

Table 7. Blood glucose values (mg/dL) between moments in the groups.

\begin{tabular}{cccccc}
\hline \multirow{2}{*}{ Group } & \multicolumn{5}{c}{ Moment $^{* 1}$} \\
\cline { 2 - 6 } & $\mathbf{1}$ & $\mathbf{2}$ & $\mathbf{3}$ & $\mathbf{4}$ & $\mathbf{5}$ \\
\hline GCO & $92.7 \pm 10.6$ & $90.3 \pm 8.3^{\circ}$ & $91.8 \pm 10.7^{\circ}$ & $99.5 \pm 12.9^{\mathrm{AB}}$ & $106.6 \pm 15.8$ \\
GFLK & $95.5 \pm 8.9^{\mathrm{bc}}$ & $93.7 \pm 11.3^{\mathrm{bc}}$ & $85.2 \pm 12.7^{\mathrm{c}}$ & $117.2 \pm 27.5^{\mathrm{Ab}}$ & $126.8 \pm 33.7^{\mathrm{a}}$ \\
GCE & $86.2 \pm 7.9^{\mathrm{b}}$ & $86.8 \pm 8.5^{\mathrm{b}}$ & $86.7 \pm 5.8^{\mathrm{b}}$ & $100.0 \pm 13.9^{\mathrm{ABb}}$ & $113.0 \pm 18.6^{\mathrm{a}}$ \\
GDEX & $84.5 \pm 11.8^{\mathrm{b}}$ & $85.3 \pm 5.9^{\mathrm{b}}$ & $85.6 \pm 12.7^{\mathrm{b}}$ & $99.1 \pm 17.6^{\mathrm{ABb}}$ & $128.8 \pm 28.2^{\mathrm{a}}$ \\
GDEXCE & $85.6 \pm 9.2^{\mathrm{b}}$ & $89.5 \pm 8.0^{\mathrm{b}}$ & $80.5 \pm 7.1^{\mathrm{b}}$ & $87.5 \pm 20.0^{\mathrm{Bb}}$ & $126.6 \pm 40.0^{\mathrm{a}}$ \\
\hline
\end{tabular}

${ }^{*}$ Mean and standard deviation; 'Student-Newman-Keuls test; different uppercase letters in the same column indicate statistical difference $(p<0.05)$ between groups; different lowercase letters in the same row indicate statistical difference $(p<0.05)$ between moments.

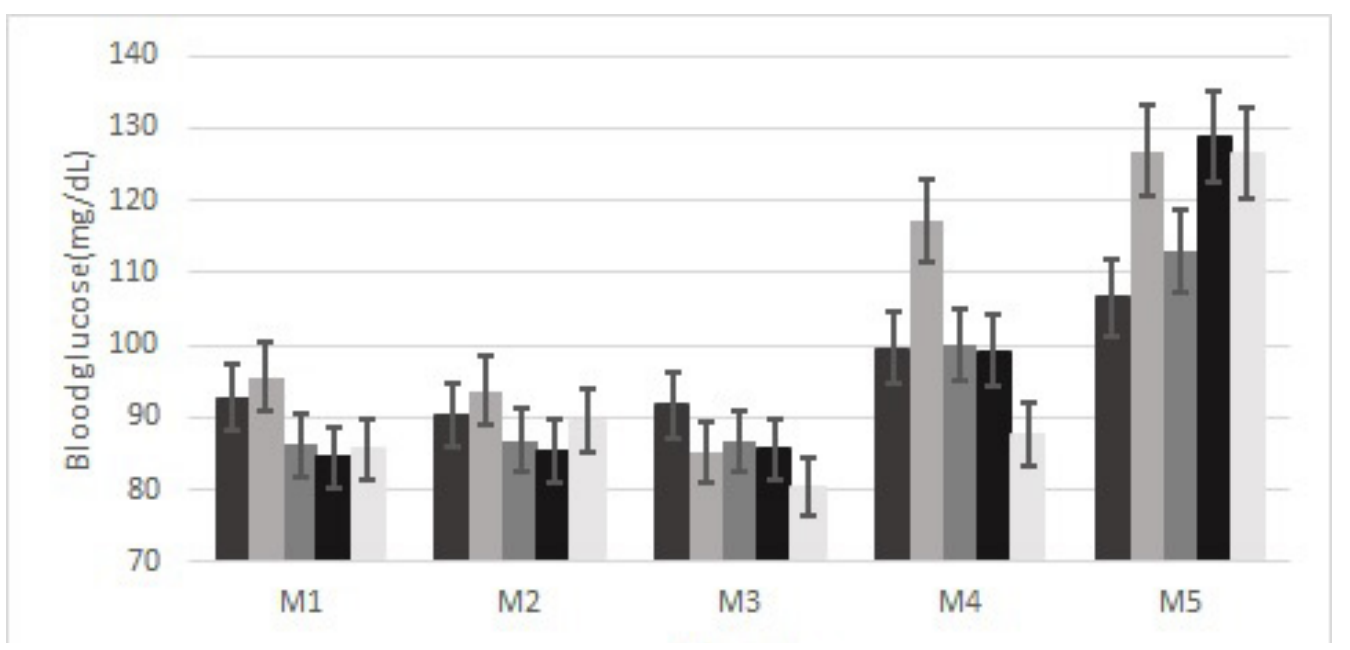

Figure 7. Graphical representation of the blood glucose variation between moments (before PAM, after PAM, after anesthetic induction (GCO) or drug administration to reach the serum level (GFLK, GCE, GDEX, GDEXCE), during clamping and ligation of the ovarian pedicle, and immediately after extubation). 
The association of dexmedetomidine and ketamine significantly reduced cortisol and blood glucose levels in comparison to two groups, respectively: GCO and GFLK.

\section{Discussion}

During the transsurgical period, nociceptive stimuli can cause cardiorespiratory changes, interfering with heart and respiratory rate and blood pressure (Bottega \& Fontana, 2010; Greene, 2010). In view of these changes, monitoring of these parameters has been essential for studies evaluating pain stimuli and for developing techniques in abdominal surgery in bitches (Basso et al., 2014; Vasiljević et al., 2015). These changes may imply reflex responses from medullary centers of breathing and circulation, characterized by hyperventilation and increased hormonal secretions from the endocrine system, which can increase peripheral vascular resistance and blood pressure (Matičić et al., 2010).

Several factors reduced body temperature, among them: heat loss through the airways; the area of body contact with the environment; and thermoregulatory depression caused by anesthesia, reducing basal metabolism (Murrell \& Hellebrekers, 2005). Leastwise, thephysiological temperature range comprises a decrease in temperature during the transsurgical period (Redondo et al., 2007).

The lower heart rate in the groups of animals that received dexmedetomidine (GDEX and GDEXCE) may be due to the possibility of this drug leading to peripheral vasoconstriction with a reflex decrease in heart rate (Murrell \& Hellebrekers, 2005). Congdon et al. (2011) found a similar result. Previous research has shown the presence of $\alpha-2$ adrenergic receptors in several organs, including liver, kidney, pancreas, and in thecentral and peripheral nervous systems, in autonomic ganglia and pre- and postsynaptic sites. The reduction in heart rate caused by $\alpha-2$ agonists is due to the stimulation of receptors in the brain and spinal cord inhibiting neuronal discharge, which leads to bradycardia and other effects (Afonso \& Reis, 2012). The subtypes of alpha-2 receptors in the organs is what determines cardiovascular effects, whichmay decrease heart rate. The activation of the $\alpha$-2b subtype present in the spinal cord and vascular epithelium is what leads to peripheral vasoconstriction and possibly a sudden fall, even characterizing peripherally mediated reflex bradycardia (Lemke, 2013).

When using a continuous infusion of dexmedetomidine at a rate of $2 \mu \mathrm{g} / \mathrm{kg} / \mathrm{h}$, Santos Otero et al. (2016) also observed a reduction in heart rate in bitches submitted to ovariosalpingohisterectomy. According to Hatschbach et al. (2005), dexmedetomidine causes bradycardia with a bolus application of $3 \mu \mathrm{g} / \mathrm{kg}$ followed by continuous infusion ( $3 \mu \mathrm{g} / \mathrm{kg} / \mathrm{h}$ ), which can be prevented with subcutaneous atropine at a dose of $0.044 \mathrm{mg} / \mathrm{kg}$. However, Congdon et al. (2011) administeredintramuscular atropine at $0.022 \mathrm{mg} / \mathrm{kg}$ after bradycardia caused by intramuscular dexmedetomidine at $10 \mu \mathrm{g} / \mathrm{kg}$. The authors do not recommend the use of atropine since it can increase mean arterial pressure and lead to cardiac tachyarrhythmias.

The minimal variation in heart rate values may correlate with the reduction of surgical stress since the response to visceral nociceptive stimuli activates the autonomous system, which can increase heart rate (Meintjes, 2012).

According to Oklü et al. (2003) and Lin (2007), ketamine leads to a sympathomimetic response from the inhibition of catecholamine uptake, which increases heart rate, among other effects.

It is noteworthy that the eventual increase in blood pressure can be attributed to the use of dexmedetomidine; however, this increase occurs initially, decreasing later (Ahmad et al., 2013). Furthermore, Lin (2007) states that ketamine can increase blood pressure. In contrast, due to the results obtained, this fact implies that dexmedetomidine administration, anesthetic induction with propofol, or the administration of drugs such as ketamine plus fentanyl can reduce blood pressure. Notwithstanding, ketamine plus dexmedetomidine can maintain blood pressure stable probably due to sympathomimetic action, supporting the fact that ketamine increases cardiac output, heart rate, and blood pressure (Oliveira et al., 2004). Villela et al. (2003) demonstrated that the doses of 1 and $2 \mu \mathrm{g} / \mathrm{kg}$, followed, respectively, by infusions at 1 and $2 \mu \mathrm{g} / \mathrm{kg} / \mathrm{h}$ of this dexmedetomidine agonist cause bradycardia in dogs; however, without significant changes in blood pressure, vascular resistance, and cardiac index.

Corroborating the Melbourne scale and the results presented mainly in GCO and GCE, Malm et al. (2005) and Muir \& Gaynor (2009) state that the vocalization parameter has a subjective indication of pain since several factors can influence it, such as anxiety, stress, and excitation. 
Basso et al. (2014) observed a significant increase in the Melbourne pain scale in animals undergoing ovariosalpingohisterectomy, using as PAM acepromazine (0.05 mg. $\left.\mathrm{kg}^{-1}, \mathrm{IM}\right)$, tramadol (4 mg. $\left.\mathrm{kg}^{-1}, \mathrm{IM}\right)$, and ketamine (0.5 mg. $\left.\mathrm{kg}^{-1}\right)$; induction with propofol (4 mg. $\left.\mathrm{kg}^{-1}\right)$; and maintenance with isoflurane. The Melbourne scale lists excessive salivation as a marker of pain, but this symptom may be influenced by some drugs. Ketamine can trigger physiological changes that may influence the assessment of animal pain, such as excessive salivation and mydriasis (Dougdale, 2010).

As the present study aimed to analyze transsurgical variables, the evaluation using the Melbourne scale did not extend long after the first analysis, nor was a comparison made with other scales. Research by Aguado et al. (2011) demonstrated a reduction in the minimum alveolar concentration (MAC) of bitches undergoing ovariosalpingohisterectomy and anesthetized with fentanyl, lidocaine, and ketamine (FLK) in comparison to morphine, lidocaine, and ketamine (MLK).This suggests an effective analgesic action of FLK. The result justifies the observation in the present study of the Melbourne scale scores of GFLK and GDEX. The higher values of GDEX in comparison to GFLK may have been influenced, as previously mentioned, by excessive salivation and mydriasis caused by the use of drugs.

Research using objective methods show that measuring cortisol and blood glucoselevels contribute to the study of analgesia in dogs with regard to the effectiveness in attenuating the neuroendocrine response to pain, considering that the elevation of cortisol increases liver gluconeogenesis and consequently hyperglycemia. This allows us to consider that cortisol and glucose increase at the moment of greatest stress during surgery, which can compare with the analgesic action of different drugs (Lacerda \& Nunes, 2008). Caldeira et al. (2006) considers that serum cortisol and blood glucose are adequate parameters for pain assessment in bitches undergoing OSH. According to Feldman \& Nelson (1985), cortisol varies between $0.5 \mu \mathrm{g} / \mathrm{dL}$ and $6.0 \mu \mathrm{g} / \mathrm{dL}$, equivalent to $13.795 \mathrm{nmol} / \mathrm{L}$ and $165.54 \mathrm{nmol} / \mathrm{L}$, respectively; and glucose varies between 70 and $110 \mathrm{mg} / \mathrm{dL}$.

The results evidenced that FLK decreased cortisol levels in the treated groups in comparison to the control group, which may indicate a reduction in pain-related stress. When observing cardiorespiratory variables after the use of FLK in dogs undergoing arthroscopy, Belmonte et al. (2013) found stability in the parameters, evidencing the analgesic action of FLK.

Zanella et al. (2009) and Rodrigues et al. (2012) point out that cortisol is a great marker for assessing both trans- and postsurgical stress. However, several factors can influence the increase in cortisol in the body, including the anesthetic drug itself (Naddaf et al., 2014). The increase in cortisol in the groups GFLK, GCE, and GDEXCE may have been due to the use of ketamine. Studies with ketamine administration in healthy humans (0.5 mg/kg/h, IV) (Hergovich et al., 2001) and equines (2.2 mg/kg, IV) (Amin \& Najim, 2011), without nociceptive stimulus, showed an increase in serum cortisol in the research subjects. When evaluating the effects of dexmedetomidine associated with ketamine in rabbits, González-Gil et al. (2015) found an increase in cortisol levels.

The significant increase in blood glucose of the groups GDEX and GDEXCE at M5 may correlate with the effect of dexmedetomidine in the body. Restitutti et al.(2012) found that dexmedetomidine significantly increases plasma glucose levels and decreases plasma insulin in dogs. Klaumann et al. (2008) states that the increase in blood glucose can be accompanied by an increase in cortisol.

Drug-influenced changes in the present study made it impossible to reliably correlate stress and the observed changes.

The significant increases in cortisol and blood glucose of GDEXCE at M5 in comparison to M1 (baseline) do not match the increased stress of these animals when considering the University of Melbourne Pain Scale. This supports the hypothesis of the influence of drugs on such changes. This study showed that the assessment of stress in dogs anesthetized with dexmedetomidine plus ketamine should be accompanied by an assessment of cortisol and blood glucose also at postsurgical times. This could reduce the serum levels of drugs, with less influence on the dosage of the substances. Moreover, it is important to perform a comparative study with different pain scales and different evaluators for greater accuracy regarding transsurgical stress in the use of dexmedetomidine associated with ketamine.

\section{Conclusions}

Cortisol and blood glucose are influenced by drugs such as dexmedetomidine and ketamine and, therefore, are not good parameters for evaluating transsurgical stress in bitches undergoing 
ovariosalpingohisterectomy under continuous infusion of these drugs in this type of experimental modeling. The increase in analgesia by combinations of fentanyl, lidocaine, and ketamine, with or without dexmedetomidine, suggests the need for more relevant studies to demonstrate the effectiveness of these associations in comparison to dexmedetomidine plus ketamine and to the fentanyl, lidocaine, and ketamine solution administered alone. Regarding stress-related hemodynamic and behavioral parameters, the Melbourne scale showed that the association between dexmedetomidine and ketamine (GDEXCE group) reduced surgical stress in bitches undergoing ovariosalpingohisterectomy. This association led to the lowest pain score, being an option for multimodal analgesia in this type of surgery.

\section{References}

Afonso, J., \& Reis, F. (2012). Dexmedetomidine: current role in anesthesia and intensive care. Revista brasileira de anestesiologia, 62(1), 118-133. http://dx.doi.org/10.1590/S0034-70942012000100015. PMid:22248773.

Aguado, D., Benito, J., \& Gómez de Segura, I. A. (2011). Reduction of the minimum alveolar concentration of isoflurane in dogs using a constant rate of infusion of lidocaine-ketamine in combination with either morphine or fentanyl. Veterinary Journal (London, England), 189(1), 63-66. http://dx.doi.org/10.1016/j.tvjl.2010.05.029. PMid:20594878.

Ahmad, R. A., Kinjavdekar, P., Aithal, H. P., Pawde, A. M., \& Kumar, D. (2013). Potential use of dexmedetomidine for different levels of sedation, analgesia and anaesthesia in dogs. Veterinarni Medicina, 58(2), 87-95.

Amin, A. A., \& Najim, I. M. (2011). Use of detomidine, butorphanol and ketamine for induction of general anesthesia in donkeys. Al-Anbar Journal of Veterinary Sciences, 4, 1-8.

Basso, P. C., Raiser, A. G., Brun, M. V., Müller, D. C. M., Lukarsewski, R., Serafini, G. M. C., \& Marconato, F. (2014). Ovariossalpingo-histerectomia em cadelas: comparação da dor e análises cardiorrespiratória, pressórica e hemogasométrica nas abordagens convencional, por NOTES híbrida e NOTES total. Arquivo Brasileiro de Medicina Veterinária e Zootecnia, 66(5), 1329-1338. http://dx.doi.org/10.1590/1678-6671.

Belmonte, E. A., Nunes, N., Thiesen, R., Lopes, P. C. F., Costa, P. F., Barbosa, V. F., Moro, J. V., Batista, P. A. C. S., \& Borges, P. A. (2013). Infusão contínua de morfina ou fentanil, associados à lidocaína e cetamina, em cães anestesiados com isofluorano. Arquivo Brasileiro de Medicina Veterinária eZootecnia, 65(4), 1075-1083. http:// dx.doi.org/10.1590/S0102-09352013000400019.

Bottega, F. H., \& Fontana, R. T. (2010). A dor como quinto sinal vital: utilização da escala de avaliação por enfermeiros de um hospital geral. Texto \& Contexto Enfermagem, 19(2), 283-290. http://dx.doi.org/10.1590/ S0104-07072010000200009.

Caldeira, F. M. C., Oliveira, H. P., Melo, E. G., Martins, C., Vieira, M. S., \& Silva, C. N. D. (2006). Cortisol sérico e glicemia em cadelas tratadas com tramadol e submetidas à ovário-histerectomia. Ciência Rural, 36(1), 155-160. http://dx.doi.org/10.1590/S0103-84782006000100023.

Castro Vaz, F., Molina, G. E., Porto, L. G. G., \& Porto, A. L. (2013). Cortisol e atividade física: será o estresse um indicador do nível de atividade física espontânea e capacidade física em idosos?. BrasíliaMédica, 50(2), 143-152.

Chohan, A. S. (2010). Anesthetic considerations in orthopedic patients with or without trauma. Topics in Companion Animal Medicine, 25(2), 107-119. http://dx.doi.org/10.1053/j.tcam.2010.01.002. PMid:20515674.

Congdon, J. M., Marquez, M., Niyom, S., \& Boscan, P. (2011). Evaluation of the sedative and cardiovascular effects of intramuscular administration of dexmedetomidine with and without concurrent atropine administration in dogs. Journal of the American Veterinary Medical Association, 239(1), 81-89. http://dx.doi.org/10.2460/ javma.239.1.81. PMid:21718200.

Deumens, R., Steyaert, A., Forget, P., Schubert, M., Lavand'homme, P., Hermans, E., \& De Kock, M. (2013). Prevention of chronic postoperative pain: cellular, molecular, and clinical insights for mechanism-based treatment approaches.Progress in Neurobiology,104,1-37. http://dx.doi.org/10.1016/j.pneurobio.2013.01.002.PMid:23410739.

Dougdale, A. (2010). Small animal sedation and premedication. In A. Dougdale. Veterinaryanaesthesia: principles to practice (pp. 30-44). Iowa: Blackwell Publishing.

Fein, A., Petrov, P., Francischi, J. N., \& Ferreira, S. H. (2011). Nociceptores: as células que sentem dor. Ribeirão Preto: Dor On Linep. Retrieved in 2016, July 20, from http://www.dol.inf.br/html/LivroNociceptores/Nociceptores.pdf

Feldman, E. C., \& Nelson, R. W. (1985) The adrenal gland. In E. C. Feldman \& R. W. Nelson. Canine and feline endocrinology and reproduction (pp. 187-322). Philadelphia: Saunders.

Field, A. (2009). Descobrindo a estatística usando o SPSS-5. Porto Alegre: Penso Editora.

González-Gil, A., Villa, A., Millán, P., Martínez-Fernández, L., \& Illera, J. C. (2015). Effects of dexmedetomidine and ketamine-dexmedetomidine with and without buprenorphine on corticoadrenal function in rabbits. Journal of the American Association for Laboratory Animal Science; JAALAS, 54(3), 299-303. PMid:26045456.

Goutal, C. M., Brugmann, B. L., \& Ryan, K. A. (2012). Insulinoma in dogs: a review. Journal of the American Animal Hospital Association, 48(3), 151-163. http://dx.doi.org/10.5326/JAAHA-MS-5745. PMid:22474047.

Greene, S. A. (2010). Chronic pain: pathophysiology and treatment implications. Topics in Companion Animal Medicine, 25(1), 5-9. http://dx.doi.org/10.1053/j.tcam.2009.10.009. PMid:20188333. 
Gündüz, M., Sakalli, Ş., Güneş, Y., Kesiktaş, E., Özcengiz, D., \& Işik, G. (2011). Comparison of effects of ketamine, ketamine-dexmedetomidine and ketamine-midazolam on dressing changes of burn patients. Journal of Anaesthesiology, Clinical Pharmacology, 27(2), 220-224. http://dx.doi.org/10.4103/0970-9185.81823. PMid:21772684.

Gutierrez-Blanco, E., Victoria-Mora, J. M., Ibancovichi-Camarillo, J. A., Sauri-Arceo, C. H., Bolio-González, M. E., Acevedo-Arcique, C. M., Marin-Cano, G., \& Steagall, P. V. (2013). Evaluation of the isoflurane-sparing effects of fentanyl, lidocaine, ketamine, dexmedetomidine, or the combination lidocaineTimes New RomanketamineTimes New Romandexmedetomidine during ovariohysterectomy in dogs. Veterinary Anaesthesia and Analgesia, 40(6), 599-609. http://dx.doi.org/10.1111/vaa.12079. PMid:23910822.

Hatschbach, E., Massone, F., Bechara, J. N., Balieiro, J. C. C., \& Barreiro, R. H. (2005). Avaliação paramétrica do cloridrato de dexmedetomidina em cães pré-tratados ou não pela atropina e tratados ou não pela quetamina. Ars Veterinária, 21(1), 22-29.

Hergovich, N., Singer, E., Agneter, E., Eichler, H. G., Graselli, U., Simhandl, C., \& Jilma, B. (2001). Comparison of the effects of ketamine and memantine on prolactin and cortisol release in men: a randomized, double-blind, placebo-controlled trial. Neuropsychopharmacology, 24(5), 590-593. PMDI 1395602.

Klaumann, P. R., Wouk, A. F. P. F., \& Sillas, T. (2008). Patofisiologia da dor. Archives of Veterinary Science, 13(1), 1-12. http://dx.doi.org/10.5380/avs.v13i1.11532.

Lacerda, M. S., \& Nunes, T. C. (2008). Efeitos do cetoprofeno e flunixin meglumine na modulação neuroendócrina à dor pós-operatória em cadelas submetidas à ovário-histerectomia. Bioscience Journal, 24(4)

Lemke, K. A. (2013) Anticolinérgiocos e sedativos. In W. J. Tranquilli, J. C. Thurmon \& K. A. Grimm. Lumb e Jones. Anestesiologia e Analgesia Veterinária (pp. 230-269). São Paulo: Roca.

Lin, H. C. (2007). Dissociative anesthetics. In W. J. Tranquilli, J. C. Thurmon \& K. A. Grimm. Lumb and Jones Veterinary Anesthesia and Analgesia (pp. 301-354). Malden: Blackwell Publishing.

Malm, C., Savassi-Rocha, P. R., Gheller, V. A., Oliveira, H. P., Lamounier, A. R., \& Foltynek, V. (2005). Ováriohisterectomia: estudo experimental comparativo entre as abordagens laparoscópica e aberta na espécie canina-III. estresse pela análise do cortisol plasmático. Arquivo Brasileiro de Medicina Veterinária e Zootecnia, 57(5), 584-590. http://dx.doi.org/10.1590/S0102-09352005000500003.

Marangoni, M. A., Castiglia, Y. M. M., \& Medeiros, T. P. (2005). Eficácia analgésica da dexmedetomidina comparada ao sufentanil em cirurgias intraperitoneais: estudo comparativo. Revista Brasileira de Anestesiologia, 55(1), 19-27. http://dx.doi.org/10.1590/S0034-70942005000100003. PMid:19471805.

Marik, P. E., \& Bellomo, R. (2013). Stress hyperglycemia: an essential survival response! Critical Care (London, England), 17(2), 305. PMid:23470218.

Matičić, D., Stejskal, M., Pećin, M., Kreszinger, M., Pirkić, B., Vnuk, D., Smolec, O., \& Rumenjak, V. (2010). Correlation of pain assessment parameters in dogs with cranial cruciate surgery. Veterinarski Arhiv, 80(5), 597-609.

Meintjes, R. A. (2012). An overview of the physiology of pain for the veterinarian. Veterinary journal (London, England: 1997), 193(2), 344-348. http://dx.doi.org/10.1016/j.tvjl.2012.03.001. PMid:22503719.

Muir, W. W., \& Gaynor, J. S. (2009). Pain behaviors. In J. Gaynor \& W. W. Muir (Eds.), Handbook of veterinary pain management (2nd ed., pp. 62-79). Mosby: Missouri. http://dx.doi.org/10.1016/B978-032304679-4.10005-X.

Murrell, J. C., \& Hellebrekers, L. J. (2005). Medetomidine and dexmedetomidine: a review of cardiovascular effects and antinociceptive properties in the dog. Veterinary Anaesthesia and Analgesia, 32(3), 117-127. http:// dx.doi.org/10.1111/j.1467-2995.2005.00233.x. PMid:15877658.

Naddaf, H., Varzi, H. N., Sabiza, S., \& Falah, H. (2014). Effects of xylazine-ketamine anesthesia on plasma levels of cortisol and vital signs during laparotomy in dogs. Open Veterinary Journal, 4(2), 85-89. PMid:26623345.

Nora FS, GrobocopatelD, Métodos de Aferição da Pressão Arterial Média; Rev Bras Anest., V.46: N4: p. 295 - 301,1996

Oklü, E., Bulutcu, F. S., Yalçın, Y., Ozbek, U., Cakalı, E., \& Bayındır, O. (2003). Which anesthetic agent alters the hemodynamic status during pediatric catheterization? Comparison of propofol versus ketamine. Journal of Cardiothoracic and Vascular Anesthesia, 17(6), 686-690. http://dx.doi.org/10.1053/j.jvca.2003.09.009. PMid:14689405.

Oliveira, C. M. B. D., Sakata, R. K., Issy, A. M., \& Garcia, J. B. S. (2004). Cetamina e analgesia preemptiva. Revista Brasileira de Anestesiologia, 54(5), 739-752. http://dx.doi.org/10.1590/S0034-70942004000500016. PMid:19471784.

Persson, J. (2013). Ketamine in pain management. CNS Neuroscience \& Therapeutics, 19(6), 396-402. http://dx.doi. org/10.1111/cns.12111. PMid:23663314.

Redondo, J. I., Rubio, M., Soler, G., Serra, I., Soler, C., \& Gómez-Villamandos, R. J. (2007). Normal values and incidence of cardiorespiratory complications in dogs during general anaesthesia. A review of 1281 cases. Journal of Veterinary Medicine Series A, 54(9), 470-477. http://dx.doi.org/10.1111/j.1439-0442.2007.00987.x. PMid:17931219.

Restitutti, F., Raekallio, M., Vainionpää, M., Kuusela, E., \& Vainio, O. (2012). Plasma glucose, insulin, free fatty acids, lactate and cortisol concentrations in dexmedetomidine-sedated dogs with or without MK-467: a peripheral $\alpha$-2 adrenoceptor antagonist. Veterinary journal (London, England : 1997), 193(2), 481-485. http:// dx.doi.org/10.1016/j.tvjl.2011.12.010. PMid:22277719.

Rodrigues, M. C., Coelho, M. C. O. C., Quessada, A. M., Lima, D. A. S. D., Sousa, J. M., \& Carvalho, C. C. (2012). Ovariosalpingohisterectomia em cadelas: comparação entre a técnica de tração uterina por via vaginal associada à celiotomia pelo flanco ea abordagem ventral mediana. Revista Portuguesa de Ciências Veterinárias, $111,165-172$. 
Rosero, E. B., \& Joshi, G. P. (2014). Preemptive, preventive, multimodal analgesia: what do they really mean?. Plastic and Reconstructive Surgery, 134(4S-2), 85S-93S. https://doi.org/10.1097/PRS.0000000000000671. PMID: 25255012.

Sampaio IBM Estatística aplicada à experimentação animal. Belo Horizonte: Fundação de Ensino e Pesquisa em Medicina Veterinária e Zootecnia, 221p.; 1998.

Santos Otero, A. R., Barbosa, V. F., Carneiro, R. L., Martins Filho, E. F., Azevedo, M. C., Santos, B. C. P., \& Costa Neto, J. M. (2016). Avaliação da infusão contínua de dexmedetomidina ou dexemedetomidina-midazolam sobre variáveis cardiorrespiratórias e qualidade da recuperação anestésica, em cadelas submetidas à ovariosalpingohisterectomia. Brazilian Journal of Veterinary Medicine, 38(2), 168-174.

Santos, L. C. D. C., Fernandes, L. S., Sepulveda, R. V., Pereira, V. G., Eleotério, R. B., \& Favarato, L. S. C. (2015). Eletroacupuntura na analgesia trans e pós-operatória de cadelas submetidas à ovariosalpingohisterectomia. Arquivo Brasileiro de Medicina Veterinária eZootecnia, 67(6), 1554-1562. http://dx.doi.org/10.1590/1678-4162-7987.

Uilenreef, J. J., Murrell, J. C., McKusick, B. C., \& Hellebrekers, L. J. (2008). Dexmedetomidine continuous rate infusion during isoflurane anaesthesia in canine surgical patients. Veterinary Anaesthesia and Analgesia, 35(1), 1-12. http://dx.doi.org/10.1111/j.1467-2995.2007.00344.x. PMid:18211626.

Vasiljević, M., Ristanović, D., Jovanović, M., Davitkov, D., Bošnjak, I., Krstić, V., \& Stanimirović, Z. (2015). Comparative analysis of parameters of intraoperative and postoperative pain in bitches undergoing laparoscopic or conventional ovariectomy. Acta Veterinaria, 65(4), 488-495. http://dx.doi.org/10.1515/acve-2015-0041.

Villela, N. R., Nascimento Júnior, P. D., \& Carvalho, L. R. D. (2003). Efeitos cardiovasculares de duas doses de dexmedetomidina: estudo experimental em cães. Revista Brasileira de Anestesiologia, 53(6), 784-796. http:// dx.doi.org/10.1590/S0034-70942003000600009. PMid:19471697.

Zanella, R., Thomazi, G., Guizzo Junior, N., Spagnolo, J. D., Guimarães, L. D., \& Brun, M. V. (2009). Cortisol plasmático como indicador de estresse em colopexias laparoscópicas com implante de tela de polipropileno em cães. Acta Scientiae Veterinariae, 37(3), 231. http://dx.doi.org/10.22456/1679-9216.16335. 